\title{
Percentile curves for Brazilian children evaluated with the Bruininks-Oseretsky Test of Motor Proficiency, 2nd edition
}

\section{Curvas percentílicas para crianças brasileiras avaliadas pelo Teste de Proficiência Motora Bruininks-Oseretsky, $2^{a}$ edição}

\author{
Luciana Ferreira \\ (D) http://orcid.org/0000-0001-5808-2334 \\ José Luiz Lopes Vieira² \\ (D) https://orcid.org/0000-0003-0453-8185 \\ Francielli Ferreira da Rocha ${ }^{3}$ \\ (D) https://orcid.org/0000-0001-7866-6070 \\ Pamela Norraila da Silva ${ }^{3}$ \\ (D) https://orcid.org/0000-0001-7277-6084 \\ Francielle Cheuczuk ${ }^{3}$ \\ (D) https://orcid.org/0000-0003-2691-5412 \\ Priscila Caçola ${ }^{4}$ \\ (D) https://orcid.org/0000-0003-2713-5733 \\ Raquel Nichele de Chaves ${ }^{5}$ \\ (1) https://orcid.org/0000-0001-6244-2080
}

\begin{abstract}
This study aimed to (1) create percentile curves and norms for the eight subtests of the Bruininks-Oseretsky Test of Motor Proficiency, $2^{\text {nd }}$ edition (BOT-2) for 6- to 10-year-old Brazilian children and to (2) compare them to the values of the original test manual. To that, we tested a sample of 931 Brazilian children (477 girls, 454 boys) with ages between 6 to 10 with the BOT-2 assessment. The LMS method was used to generate the percentile curves and normative values, with the LMSchartmaker Pro software version 2.54. Results demonstrate that girls had significantly higher scores for the fine motor precision, fine motor integration, manual dexterity and balance subtests, while boys had significantly higher scores on upper-limb coordination, running speed and agility, and the strength subtests. The findings also indicated higher values for the Brazilian group in the subtests of bilateral coordination, running speed and agility, balance, and upper-limb coordination when compared to the North American normative sample. The percentile curves illustrate the increase in motor proficiency levels as age increases, with different trajectories for each subtest. Future studies should continue the investigation of cultural norms and appropriate assessments for the Brazilian population. Here, the creation of percentile curves and norms that are better suited for the Brazilian population can significantly help with assessment and intervention for motor development in distinct settings and with typical and atypical school-age children.
\end{abstract}

Key words: Children; Motor development; Motor proficiency; Norms; Percentile curves.

Resumo - Este estudo objetivou (1) criar curvas e normas percentílicas para os oito subtestes do Teste de Proficiência Motora Bruininks-Oseretsky, 2a edição (BOT-2) para crianças brasileiras de 6 a 10 anos e compará-las com os valores do manual de teste original. Para tanto, testamos uma amostra de 931 crianças brasileiras (477 meninas, 454 meninos) com idades entre 6 a 10 anos com a avaliação do BOT-2. O método LMS foi usado para gerar as curvas de percentil e valores normativos, utilizando o software LMSchartmaker Pro versão 2.54. Os resultados demonstram que as meninas tiveram escores significativamente mais altos nos subtestes de precisão motora fina, integração motora fina, destreza manual e equilibrio, enquanto os meninos tiveram escores significativamente mais altos nos subtestes de coordenação de membros superiores, velocidade de corrida e agilidade e força. Os resultados também indicaram valores mais elevados para o grupo brasileiro nos subtestes de coordenação bilateral, corrida de velocidade e agilidade, equilíbrio e coordenação dos membros superiores quando comparados com a amostra normativa norte-americana. As curvas percentílicas ilustram o aumento nos niveis de proficiência motora à medida que a idade aumenta, com diferentes trajetórias para cada subteste. Estudos futuros devem continuar a investigação de normas culturais e avaliaçôes apropriadas para a população brasileira. Neste estudo, a criação de curvas e normas percentílicas mais adequadas para a população brasileira pode ajudar significativamente na avaliação e intervenção para o desenvolvimento motor em diferentes contextos e com crianças em idade escolar tipicas e atípicas.

Palavras-chave: Crianças; Desenvolvimento motor; Proficiência motora; Normas; Curvas percentílicas.
1 State University of Parana. Paranavai, PR. Brazil.

\section{Universidad Católica del Maule.} Talca. Chile.

3 State University of Maringa. Maringa, PR. Brazil.

4 University of Texas at Arlington. Arlington, TX. United States of America.

5 Federal University of Technology Paraná. Curitiba, PR. Brazil.

Received: 06 May 2019 Accepted: 06 September 2019

How to cite this article Ferreira L, Vieira JLL, Rocha FF, Silva PN, Cheuczuk F, Caçola P, Chaves RN. Percentile curves for Brazilian children evaluated with the Bruininks-Oseretsky Test of Motor Proficiency, 2nd edition. Rev Bras Cineantropom Desempenho Hum 2020, 22:e65027. D0I: http://dx.doi. org/10.1590/1980-0037.2020v22e65027

Copyright: This work is licensed under a Creative Commons Attribution 4.0 International License. 


\section{INTRODUCTION}

Motor proficiency is the ability to perform several motor skills efficiently, such as running, kicking, and jumping. Motor proficiency can also be defined as motor "competence" ${ }^{2}$ - determined that motor competence is a global term reflecting various terminologies that have been used in previous literature (i.e., motor proficiency, motor performance, fundamental movement/motor skill, motor ability, and motor coordination) describing goal-directed human movement. Here, we examine motor proficiency in the context of a cultural setting, with a Brazilian population of schoolage children. Motor proficiency is key to a healthy development, as low motor proficiency in childhood has been associated with anxiety and depression, poor social skills and low self-esteem, lower quality of life, low cardiorespiratory fitness and obesity. Given these negative association, early identification of problems through effective assessment for further intervention is extremely important ${ }^{3}$.

Several standardized test batteries are used for assessment of motor proficiency in childhood - among those, the most commonly used and wellknown are the Test of Gross Motor Development (TGMD) Movement Assessment Battery for Children, $2^{\text {nd }}$ edition (MABC-2) Körperkoordinationstest Für Kinder (KTK) and the Bruininks-Oseretsky Test of Motor Proficiency, $2^{\text {nd }}$ Edition (BOT-2). All of the tests above have been validated for Brazilian children, except for the KTK and BOT-2 assessments. The TGMD-3 was translated and is a valid and reliable instrument for Brazilian children ${ }^{4}$. The MABC- 2 was also translated to the Brazilian population, and the authors confirmed that the original standardized scores established for the MABC-2 are valid in Brazilian children ${ }^{4}$.

Here, we will address the creation of percentile curves and norms with the BOT-2 assessment. The BOT-2 is one of the most comprehensive assessments for motor proficiency, and also one of the most widely used test of motor skills $s^{5}$. The BOT-2 has a wide range of components and provides an overview of the child's motor proficiency level ${ }^{6}$. Cools ${ }^{7}$ report that the BOT-2 is a very detailed instrument that provides information on skill mastering: beneath and above skill level, while accounting for qualitative and quantitative aspects of movement behavior. Among its main qualities, BOT2 has good-to-excellent data reliability ${ }^{6,7}$, it categorizes motor proficiency for a wide age group ( 4 to 21 years old), in addition to providing a detailed motor evaluation through the subtests that can be evaluated separately ${ }^{7}$.

The BOT-2 is considered one of the most internationally used batteries $^{5}$. Therefore, careful evaluation is required, especially with respect to standards and cut-off points suggested for other samples. The creation of normative values for Brazilian children can be justified by the great geographic extent, cultural, ethnic and socioeconomic diversity, which can affect motor proficiency. On the other hand, environmental, cultural and even genetic differences can be seen within the same country or region, which are mainly related to social conditions, health and the daily 
routines of children and, thus, more precise readings that are closer to reality are required ${ }^{3}$. Based on the above considerations, the present study aimed to (1) calculate percentile curves for the eight BOT-2 subtests, and to (2) compare and contrast the results with the values determined in the original test manual.

\section{METHOD}

\section{Participants}

The sample comprised 6-to-10-year-old students, of both sexes, enrolled in public and private elementary schools of the city of Maringa. The city of Maringa, situated in the North Central region of Paraná, has approximately 403,063 inhabitants and a Human Development Index (HDI) of 0.808, which is considered high. In 2015, there were 16.335 children enrolled in elementary education in the municipal school system, and 7.362 in private schools. After this survey, a sample calculation was performed based on the formula proposed to establish the necessary number of 6-to-10-yearold children who would represent the city of Maringa. Therefore, 603 children enrolled in public schools and 328 children enrolled in private schools were included in the sample, for a total of 931 (477 girls and 454 boy). All procedures were approved by the Institutional Review Board (IRB) of the local university).

The sample distribution according to age and sex: 6 years old (boys: 45; girls: 50); 7 years old (boys: 80; girls: 97); 8 years old (boys: 128; girls: 120); 9 years old (boys: 133; girls: 135) and 10 years old (boys: 68; girls: 75), totalizing 454 boys; 477 girls (931 total of students).

\section{Instruments}

The Bruininks-Oseretsky Test of Motor Proficiency - Second Edition ${ }^{6}$ is a standardized test that measures motor performance in individuals ages 4- to 21 years. It assesses both fine- and gross motor skill performance using 53 items divided in four motor composite areas including Fine Manual Control, Manual Coordination, Body Coordination, and Strength and Agility.

The composite scores are derived from eight subscales (Fine Motor Precision: Score (points) 0 - 41; Fine Motor Integration: Score (points) 0 - 40; Manual Dexterity: Score (points) 0 - 45; Upper-Limb Coordination: Score (points) 0 - 39; Bilateral Coordination: Score (points) $0-24$; Balance: Score (points) 0 - 37; Running Speed: Score (points) 0 - 52 and Agility and Strength: Score (points) 0 - 42). These scores are converted into standard scores and percentiles according to the manual, and norms for each gender are used. In addition, the following descriptive categories according to the percentile rank as described in the test manual are utilized for total motor competence: well-above average (percentile 98 or greater), above average (percentile 84-97), average (percentile 18-83), below average (percentile 3-17), and well-below average (percentile 2 or less). Here, we utilized a translated version from English to Portuguese. 


\section{Procedures}

Three trained researchers administered the assessment in an isolated space in each child's school. Each child was individually evaluated during the performance of the 53 tasks, with each assessment lasting 35 to 60 minutes. Initially, the evaluator provided the child with the necessary instructions for each task. The sequence of the tests rigorously followed the proposal of the manual, starting with the tasks related to manual dexterity and finishing with strength tasks, since reversing the application order could compromise motor performance in certain tasks due to tiredness and/or fatigue.

\section{Data analysis}

Percentile curves were obtained by using the LMS method, implemented with the LMSchartmaker Pro software version 2.548. In order to normalize the distribution of values in each of the variables, the LMS method uses the Box-Cox transformation, specific for each age; and L, M and S values are Cubic Splines in each age range. This method consists of three smoothing age-specific curves, which are referred to as L curve (Box-Cox transformation), $\mathrm{M}$ curve (median) and $\mathrm{S}$ curve (coefficient of variation) based on the following equation:

$$
C_{100 a}(t)=M(t)\left[1+L(t) S(t) Z_{\alpha}\right]^{1 / L(t)}
$$

Where $Z \alpha$ is the equivalent normal deviation for the total sample, $\alpha$ and $\mathrm{C} 100 \alpha(\mathrm{t})$ are the corresponding percentiles. The smoothing complexity of each curve was measured through the degrees of freedom equivalent for $\mathrm{L}(t), \mathrm{M}(t)$ and $\mathrm{S}(t)$. Q Tests ${ }^{8}$ were used for fit adequacy, as well as representations of Worm plots ${ }^{8,9}$.

\section{RESULTS}

Table 1 shows the descriptive results of both sexes at different ages for the eight BOT-2 subtests. In general, boys and girls showed increases mean values by age. The maximum values reached at all ages by girls in the subtests of Balance (37 points) and Bilateral Coordination (24 points) are highlighted.

Figures 1 and 2 shows the percentile reference curves for the eight BOT2 subtests. In all subtests, there was an increase in motor proficiency by age, whose magnitude is conditioned to both sex and the subtest. In general, girls showed higher scores in the subtests of fine motor precision, fine motor integration, manual dexterity, and balance. Boys, on the other hand, presented higher scores in the subtests related to upper-limb coordination, running speed and agility, and muscular strength. Considering the bilateral coordination subtest, the girls showed higher scores up to 8 years of age.

Table 2 shows the percentiles for each age (P3, P10, P50, P75, P90, P97) of boys and girls by each subtest. In the fine motor precision subtest, the mean value (P50) of boys and girls at ten years of age is very similar ( 34.04 points). Similarly, in the fine motor integration subtest, girls showed 
a mean value (P50), only 0.9 points higher compared to boys. The values increase as age increases, for example, at 10 years of age, girls showed a mean value of 28.69 points, whereas the boys scored 24.75 points. Considering the bilateral coordination subtest, there was a progressive increase for both sexes, with a mean value (P50) of 6 years of age of 18.08 points for girls and of 16.94 points for boys, and reaching 22.53 points and 22.76 points, respectively. Boys showed better performance than girls across all ages in the upper-limb coordination subtest. This difference was seen at all ages. The running speed and agility subtest showed a mean value (P50) of 29.42 points for 6-year-old boys and 35.81 points for 10 -year-old boys. In strength, a clear distinction emerged, where the boys showed higher scores at all ages.

Table 1. Mean, standard deviation and amplitude for the eight BOT-2 subtests, according to sex and age.

\begin{tabular}{|c|c|c|c|c|c|c|}
\hline \multirow{3}{*}{ Variables } & \multirow{3}{*}{ Gender } & \multicolumn{5}{|l|}{ Age } \\
\hline & & 6 & 7 & 8 & 9 & 10 \\
\hline & & $\begin{array}{l}\text { Mean }( \pm) \text { SD } \\
\text { min - max }\end{array}$ & $\begin{array}{l}\text { Mean }( \pm) \text { SD } \\
\min -\max \end{array}$ & $\begin{array}{l}\text { Mean }( \pm) \text { SD } \\
\min -\max \end{array}$ & $\begin{array}{l}\text { Mean }( \pm) \text { SD } \\
\min -\max \end{array}$ & $\begin{array}{l}\text { Mean }( \pm) \text { SD } \\
\min -\max \end{array}$ \\
\hline \multirow{2}{*}{ Fine Motor Precision } & Boys & $\begin{array}{l}23.68 \pm 6.03 \\
10-35\end{array}$ & $\begin{array}{l}27.95 \pm 5.65 \\
11-36\end{array}$ & $\begin{array}{l}30.94 \pm 4.81 \\
18-40\end{array}$ & $\begin{array}{l}32.78 \pm 4.02 \\
22-39\end{array}$ & $\begin{array}{l}33.55 \pm 3.70 \\
20-40\end{array}$ \\
\hline & Girls & $\begin{array}{l}26.94 \pm 5.71 \\
15-40\end{array}$ & $\begin{array}{l}29.58 \pm 4.38 \\
19-39\end{array}$ & $\begin{array}{l}32.66 \pm 3.77 \\
20-39\end{array}$ & $\begin{array}{l}33.61 \pm 3.51 \\
22-40\end{array}$ & $\begin{array}{l}34.97 \pm 3.04 \\
26-41\end{array}$ \\
\hline \multirow{2}{*}{$\begin{array}{l}\text { Fine Motor Integra- } \\
\text { tion }\end{array}$} & Boys & $\begin{array}{l}21.86 \pm 5.71 \\
10-35\end{array}$ & $\begin{array}{l}25.78 \pm 6.08 \\
7-36\end{array}$ & $\begin{array}{l}28.21 \pm 4.56 \\
15-39\end{array}$ & $\begin{array}{l}29.38 \pm 4.06 \\
17-39\end{array}$ & $\begin{array}{l}30.09 \pm 4.54 \\
15-38\end{array}$ \\
\hline & Girls & $\begin{array}{l}23.90 \pm 5.67 \\
12-35\end{array}$ & $\begin{array}{l}26.68 \pm 5.11 \\
10-38\end{array}$ & $\begin{array}{l}29.26 \pm 4.19 \\
18-37\end{array}$ & $\begin{array}{l}30.18 \pm 3.70 \\
19-38\end{array}$ & $\begin{array}{l}31.56 \pm 4.11 \\
16-39\end{array}$ \\
\hline \multirow{2}{*}{ Manual Dexterity } & Boys & $\begin{array}{l}18.89 \pm 3.37 \\
12-26\end{array}$ & $\begin{array}{l}21.34 \pm 4.04 \\
8-31\end{array}$ & $\begin{array}{l}23.90 \pm 3.75 \\
15-34\end{array}$ & $\begin{array}{l}26.65 \pm 3.84 \\
14-35\end{array}$ & $\begin{array}{l}26.67 \pm 4.46 \\
11-36\end{array}$ \\
\hline & Girls & $\begin{array}{l}19.88 \pm 3.46 \\
12-27\end{array}$ & $\begin{array}{l}22.86 \pm 3.75 \\
15-32\end{array}$ & $\begin{array}{l}25.98 \pm 3.47 \\
16-34\end{array}$ & $\begin{array}{l}27.73 \pm 4.03 \\
16-39\end{array}$ & $\begin{array}{l}29.29 \pm 4.13 \\
17-41\end{array}$ \\
\hline \multirow{2}{*}{$\begin{array}{l}\text { Upper-Limb Coordi- } \\
\text { nation }\end{array}$} & Boys & $\begin{array}{l}26.24 \pm 7.34 \\
10-37\end{array}$ & $\begin{array}{l}28.74 \pm 6.70 \\
9-39\end{array}$ & $\begin{array}{l}32.91 \pm 5.39 \\
15-39\end{array}$ & $\begin{array}{l}34.78 \pm 4.21 \\
12-39\end{array}$ & $\begin{array}{l}35.87 \pm 3.14 \\
24-39\end{array}$ \\
\hline & Girls & $\begin{array}{l}20.42 \pm 7.49 \\
4-38\end{array}$ & $\begin{array}{l}26.92 \pm 6.63 \\
6-38\end{array}$ & $\begin{array}{l}29.74 \pm 5.64 \\
10-39\end{array}$ & $\begin{array}{l}31.96 \pm 5.44 \\
3-39\end{array}$ & $\begin{array}{l}34.03 \pm 3.39 \\
26-39\end{array}$ \\
\hline \multirow{2}{*}{$\begin{array}{l}\text { Bilateral Coordina- } \\
\text { tion }\end{array}$} & Boys & $\begin{array}{l}16.60 \pm 4.11 \\
6-23\end{array}$ & $\begin{array}{l}19.00 \pm 3.42 \\
8-24\end{array}$ & $\begin{array}{l}21.30 \pm 2.76 \\
8-24\end{array}$ & $\begin{array}{l}21.96 \pm 2.52 \\
10-24\end{array}$ & $\begin{array}{l}21.77 \pm 2.48 \\
15-24\end{array}$ \\
\hline & Girls & $\begin{array}{l}18.08 \pm 3.65 \\
8-24\end{array}$ & $\begin{array}{l}20.39 \pm 3.20 \\
7-24\end{array}$ & $\begin{array}{l}21.10 \pm 3.15 \\
7-24\end{array}$ & $\begin{array}{l}21.81 \pm 2.20 \\
13-24\end{array}$ & $\begin{array}{l}22.33 \pm 1.90 \\
16-24\end{array}$ \\
\hline \multirow{2}{*}{ Balance } & Boys & $\begin{array}{l}30.22 \pm 3.30 \\
22-35\end{array}$ & $\begin{array}{l}31.64 \pm 3.36 \\
20-37\end{array}$ & $\begin{array}{l}32.52 \pm 2.88 \\
23-37\end{array}$ & $\begin{array}{l}33.32 \pm 2.67 \\
26-37\end{array}$ & $\begin{array}{l}33.22 \pm 2.67 \\
25-37\end{array}$ \\
\hline & Girls & $\begin{array}{l}30.94 \pm 3.10 \\
22-37\end{array}$ & $\begin{array}{l}32.25 \pm 2.55 \\
23-37\end{array}$ & $\begin{array}{l}33.21 \pm 2.57 \\
22-37\end{array}$ & $\begin{array}{l}33.44 \pm 2.71 \\
24-37\end{array}$ & $\begin{array}{l}33.56 \pm 2.48 \\
27-37\end{array}$ \\
\hline \multirow{2}{*}{$\begin{array}{l}\text { Running Speed and } \\
\text { Agility }\end{array}$} & Boys & $\begin{array}{l}30.40 \pm 4.01 \\
23-39\end{array}$ & $\begin{array}{l}31.10 \pm 4.91 \\
16-42\end{array}$ & $\begin{array}{l}33.84 \pm 4.30 \\
20-44\end{array}$ & $\begin{array}{l}35.29 \pm 4.39 \\
23-48\end{array}$ & $\begin{array}{l}35.24 \pm 4.70 \\
16-44\end{array}$ \\
\hline & Girls & $\begin{array}{l}29.20 \pm 4.60 \\
16-39\end{array}$ & $\begin{array}{l}30.91 \pm 4.02 \\
15-39\end{array}$ & $\begin{array}{l}32.78 \pm 3.96 \\
19-40\end{array}$ & $\begin{array}{l}34.34 \pm 4.11 \\
22-48\end{array}$ & $\begin{array}{l}34.89 \pm 3.51 \\
27-45\end{array}$ \\
\hline \multirow{2}{*}{ Strength } & Boys & $\begin{array}{l}16.42 \pm 5.27 \\
3-27\end{array}$ & $\begin{array}{l}18.73 \pm 5.26 \\
4-29\end{array}$ & $\begin{array}{l}20.65 \pm 4.90 \\
8-33\end{array}$ & $\begin{array}{l}22.35 \pm 5.21 \\
8-33\end{array}$ & $\begin{array}{l}22.65 \pm 5.57 \\
8-32\end{array}$ \\
\hline & Girls & $\begin{array}{l}15.16 \pm 4.79 \\
4-27\end{array}$ & $\begin{array}{l}17.02 \pm 4.87 \\
5-27\end{array}$ & $\begin{array}{l}18.92 \pm 4.85 \\
8-29\end{array}$ & $\begin{array}{l}19.64 \pm 4.85 \\
8-29\end{array}$ & $\begin{array}{l}20.64 \pm 5.04 \\
8-33\end{array}$ \\
\hline
\end{tabular}

Note. SD: standard deviation; Min: Minimum; Max: Maximum.

The comparison of scores between Brazilian and North American children is shown in Figure 3. 

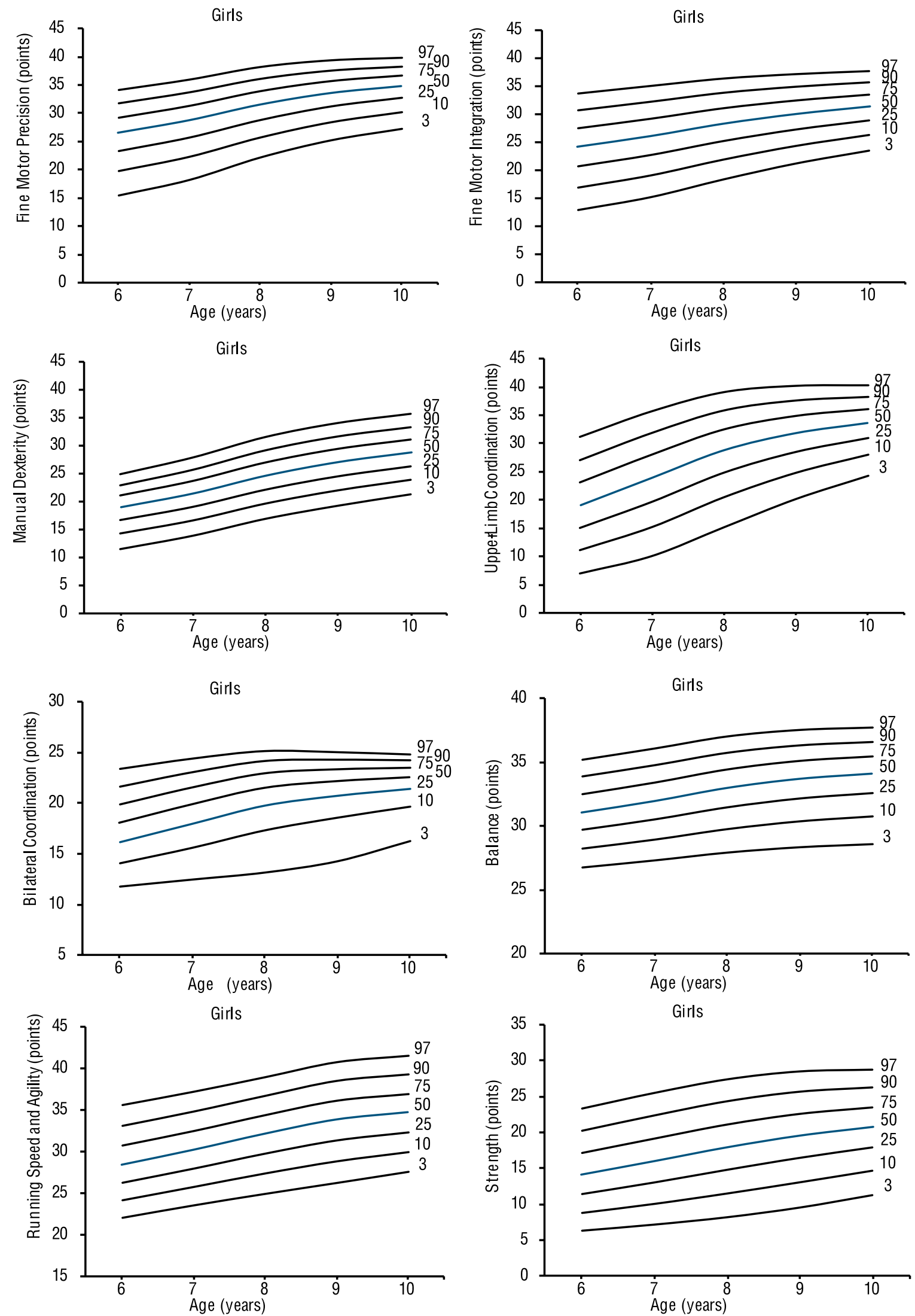

Figure 1. Percentage curves of the eight BOT-2 subtests for boys. 
Table 2. Percentile numerical values (P3, P10, P25, P50, P75, P90, P97) of B0T-2 subtests according to sex and age.

\begin{tabular}{|c|c|c|c|c|c|c|c|c|c|c|c|c|c|c|}
\hline \multirow{3}{*}{ Age } & \multicolumn{7}{|c|}{ Boys } & \multicolumn{7}{|c|}{ Girls } \\
\hline & \multicolumn{14}{|c|}{ Fine Motor Precision } \\
\hline & P3 & P10 & P25 & P50 & P75 & P90 & P97 & P3 & P10 & P25 & P50 & P75 & $\mathrm{P} 90$ & P97 \\
\hline 6 & 10.07 & 14.95 & 19.05 & 22.70 & 26.05 & 29.17 & 32.10 & 15.50 & 19.84 & 23.39 & 26.48 & 29.23 & 31.76 & 34.09 \\
\hline 7 & 13.43 & 18.43 & 22.60 & 26.28 & 29.62 & 32.71 & 35.60 & 18.25 & 22.37 & 25.76 & 28.70 & 31.33 & 33.73 & 35.94 \\
\hline 8 & 18.13 & 22.74 & 26.58 & 29.94 & 32.97 & 35.75 & 38.34 & 22.21 & 25.79 & 28.83 & 31.50 & 33.92 & 36.13 & 38.18 \\
\hline 9 & 21.92 & 26.21 & 29.61 & 32.49 & 35.02 & 37.29 & 39.36 & 25.24 & 28.49 & 31.21 & 33.58 & 35.69 & 37.62 & 39.38 \\
\hline \multirow[t]{3}{*}{10} & 25.61 & 29.05 & 31.77 & 34.04 & 36.03 & 37.80 & 39.40 & 27.27 & 30.28 & 32.73 & 34.83 & 36.67 & 38.33 & 39.83 \\
\hline & \multicolumn{14}{|c|}{ Fine Motor Integration } \\
\hline & P3 & P10 & P25 & P50 & P75 & P90 & P97 & P3 & P10 & P25 & P50 & P75 & P90 & P97 \\
\hline 6 & 11.67 & 14.58 & 17.68 & 20.98 & 24.45 & 28.09 & 31.88 & 12.79 & 16.89 & 20.63 & 24.11 & 27.41 & 30.56 & 33.59 \\
\hline 7 & 13.97 & 17.48 & 20.92 & 24.30 & 27.64 & 30.94 & 34.21 & 15.13 & 19.08 & 22.67 & 26.00 & 29.14 & 32.13 & 34.98 \\
\hline 8 & 17.25 & 21.08 & 24.50 & 27.63 & 30.53 & 33.27 & 35.86 & 18.34 & 21.92 & 25.18 & 28.21 & 31.06 & 33.76 & 36.34 \\
\hline 9 & 19.76 & 23.52 & 26.65 & 29.39 & 31.84 & 34.08 & 36.15 & 21.22 & 24.37 & 27.26 & 29.94 & 32.47 & 34.86 & 37.14 \\
\hline \multirow[t]{3}{*}{10} & 20.95 & 24.84 & 27.86 & 30.38 & 32.57 & 34.53 & 36.30 & 23.54 & 26.32 & 28.89 & 31.28 & 33.53 & 35.66 & 37.69 \\
\hline & \multicolumn{14}{|c|}{ Manual Dexterity } \\
\hline & P3 & P10 & P25 & P50 & P75 & P90 & P97 & P3 & P10 & P25 & P50 & P75 & $\mathrm{P90}$ & P97 \\
\hline 6 & 12.20 & 13.99 & 15.87 & 17.84 & 19.92 & 22.09 & 24.35 & 11.53 & 14.20 & 16.61 & 18.85 & 20.95 & 22.94 & 24.84 \\
\hline 7 & 14.06 & 15.89 & 17.84 & 19.93 & 22.16 & 24.53 & 27.03 & 13.92 & 16.54 & 18.99 & 21.33 & 23.56 & 25.72 & 27.80 \\
\hline 8 & 16.44 & 18.48 & 20.63 & 22.89 & 25.27 & 27.75 & 30.35 & 16.95 & 19.57 & 22.09 & 24.52 & 26.89 & 29.19 & 31.44 \\
\hline 9 & 18.28 & 20.71 & 23.13 & 25.56 & 27.98 & 30.41 & 32.83 & 19.30 & 21.95 & 24.51 & 26.97 & 29.35 & 31.67 & 33.93 \\
\hline \multirow[t]{3}{*}{10} & 19.93 & 22.36 & 24.75 & 27.08 & 29.38 & 31.64 & 33.87 & 21.33 & 23.85 & 26.30 & 28.69 & 31.03 & 33.31 & 35.56 \\
\hline & \multicolumn{14}{|c|}{ Upper-Limb Coordination } \\
\hline & P3 & P10 & $\mathrm{P} 25$ & P50 & P75 & P90 & P97 & P3 & P10 & P25 & P50 & P75 & $\mathrm{P90}$ & P97 \\
\hline 6 & 16.05 & 19.85 & 23.56 & 27.17 & 30.72 & 34.21 & 37.65 & 7.08 & 11.09 & 15.09 & 19.10 & 23.10 & 27.10 & 31.10 \\
\hline 7 & 17.43 & 22.12 & 26.10 & 29.63 & 32.84 & 35.80 & 38.58 & 10.15 & 15.16 & 19.72 & 23.98 & 28.03 & 31.91 & 35.66 \\
\hline 8 & 19.61 & 25.59 & 29.63 & 32.79 & 35.45 & 37.75 & 39.81 & 15.23 & 20.44 & 24.89 & 28.85 & 32.49 & 35.87 & 39.06 \\
\hline 9 & 22.28 & 28.92 & 32.47 & 35.01 & 37.02 & 38.70 & 40.16 & 20.23 & 24.76 & 28.56 & 31.88 & 34.88 & 37.62 & 40.17 \\
\hline \multirow[t]{3}{*}{10} & 25.85 & 31.63 & 34.37 & 36.24 & 37.69 & 38.88 & 39.89 & 24.31 & 27.95 & 31.01 & 33.68 & 36.07 & 38.25 & 40.27 \\
\hline & \multicolumn{14}{|c|}{ Bilateral Coordination } \\
\hline & P3 & P10 & $\mathrm{P} 25$ & $\mathrm{P} 50$ & P75 & P90 & P97 & P3 & P10 & P25 & P50 & P75 & P90 & P97 \\
\hline 6 & 12.60 & 13.84 & 15.28 & 16.94 & 18.88 & 21.17 & 23.88 & 11.79 & 14.05 & 16.13 & 18.08 & 19.92 & 21.67 & 23.36 \\
\hline 7 & 13.52 & 15.26 & 17.00 & 18.72 & 20.44 & 22.14 & 23.84 & 12.49 & 15.59 & 17.94 & 19.88 & 21.56 & 23.05 & 24.41 \\
\hline 8 & 14.37 & 17.22 & 19.29 & 20.95 & 22.37 & 23.61 & 24.72 & 13.19 & 17.32 & 19.72 & 21.49 & 22.91 & 24.12 & 25.18 \\
\hline 9 & 14.40 & 18.80 & 20.85 & 22.25 & 23.34 & 24.24 & 25.01 & 14.31 & 18.57 & 20.68 & 22.15 & 23.29 & 24.25 & 25.07 \\
\hline \multirow[t]{3}{*}{10} & 16.38 & 20.18 & 21.73 & 22.76 & 23.54 & 24.17 & 24.70 & 16.31 & 19.66 & 21.35 & 22.53 & 23.44 & 24.19 & 24.83 \\
\hline & & & & & & & $\mathrm{Bal}$ & nce & & & & & & \\
\hline & P3 & P10 & P25 & P50 & P75 & $\mathrm{P} 90$ & P97 & P3 & P10 & P25 & P50 & P75 & P90 & P97 \\
\hline 6 & 25.04 & 27.19 & 29.08 & 30.79 & 32.35 & 33.80 & 35.14 & 26.73 & 28.22 & 29.67 & 31.09 & 32.49 & 33.85 & 35.19 \\
\hline 7 & 25.59 & 27.85 & 29.82 & 31.59 & 33.20 & 34.68 & 36.05 & 27.29 & 28.93 & 30.49 & 31.97 & 33.39 & 34.76 & 36.07 \\
\hline 8 & 26.42 & 28.74 & 30.75 & 32.56 & 34.19 & 35.69 & 37.09 & 27.92 & 29.77 & 31.44 & 32.99 & 34.42 & 35.75 & 37.01 \\
\hline 9 & 27.18 & 29.48 & 31.46 & 33.23 & 34.82 & 36.29 & 37.64 & 28.35 & 30.39 & 32.14 & 33.69 & 35.08 & 36.35 & 37.52 \\
\hline 10 & 28.25 & 30.20 & 31.98 & 33.62 & 35.15 & 36.58 & 37.94 & 28.59 & 30.78 & 32.57 & 34.09 & 35.43 & 36.62 & 37.71 \\
\hline & & & & & & Run & hing Spe & $d$ and $A$ & gility & & & & & \\
\hline & P3 & P10 & P25 & $\mathrm{P} 50$ & P75 & P90 & P97 & P3 & P10 & P25 & P50 & P75 & P90 & P97 \\
\hline 6 & 21.07 & 23.90 & 26.68 & 29.42 & 32.12 & 34.79 & 37.44 & 22.12 & 24.13 & 26.23 & 28.42 & 30.71 & 33.08 & 35.54 \\
\hline 7 & 22.64 & 25.44 & 28.17 & 30.83 & 33.44 & 36.00 & 38.51 & 23.60 & 25.76 & 27.96 & 30.20 & 32.48 & 34.80 & 37.15 \\
\hline 8 & 25.01 & 27.72 & 30.35 & 32.91 & 35.40 & 37.84 & 40.24 & 24.97 & 27.40 & 29.78 & 32.12 & 34.42 & 36.68 & 38.91 \\
\hline 9 & 26.86 & 29.70 & 32.40 & 34.99 & 37.47 & 39.87 & 42.19 & 26.26 & 28.87 & 31.38 & 33.81 & 36.18 & 38.48 & 40.72 \\
\hline 10 & 27.34 & 30.37 & 33.18 & 35.81 & 38.31 & 40.68 & 42.95 & 27.58 & 29.99 & 32.36 & 34.69 & 36.98 & 39.25 & 41.49 \\
\hline & & & & & & & Stre & gith & & & & & & \\
\hline & P3 & P10 & P25 & P50 & P75 & $\mathrm{P90}$ & P97 & P3 & P10 & P25 & P50 & P75 & P90 & P97 \\
\hline 6 & 6.95 & 9.81 & 12.80 & 15.88 & 19.04 & 22.27 & 25.57 & 6.33 & 8.77 & 11.39 & 14.18 & 17.11 & 20.18 & 23.38 \\
\hline 7 & 8.33 & 11.32 & 14.40 & 17.55 & 20.75 & 24.01 & 27.30 & 7.19 & 10.05 & 13.00 & 16.04 & 19.15 & 22.31 & 25.54 \\
\hline 8 & 10.08 & 13.31 & 16.54 & 19.76 & 22.97 & 26.17 & 29.37 & 8.22 & 11.51 & 14.75 & 17.96 & 21.13 & 24.27 & 27.40 \\
\hline 9 & 11.65 & 15.20 & 18.60 & 21.88 & 25.07 & 28.19 & 31.23 & 9.57 & 13.09 & 16.41 & 19.58 & 22.63 & 25.60 & 28.49 \\
\hline 10 & 12.90 & 16.66 & 20.10 & 23.31 & 26.36 & 29.27 & 32.07 & 11.30 & 14.73 & 17.86 & 20.78 & 23.55 & 26.19 & 28.73 \\
\hline
\end{tabular}



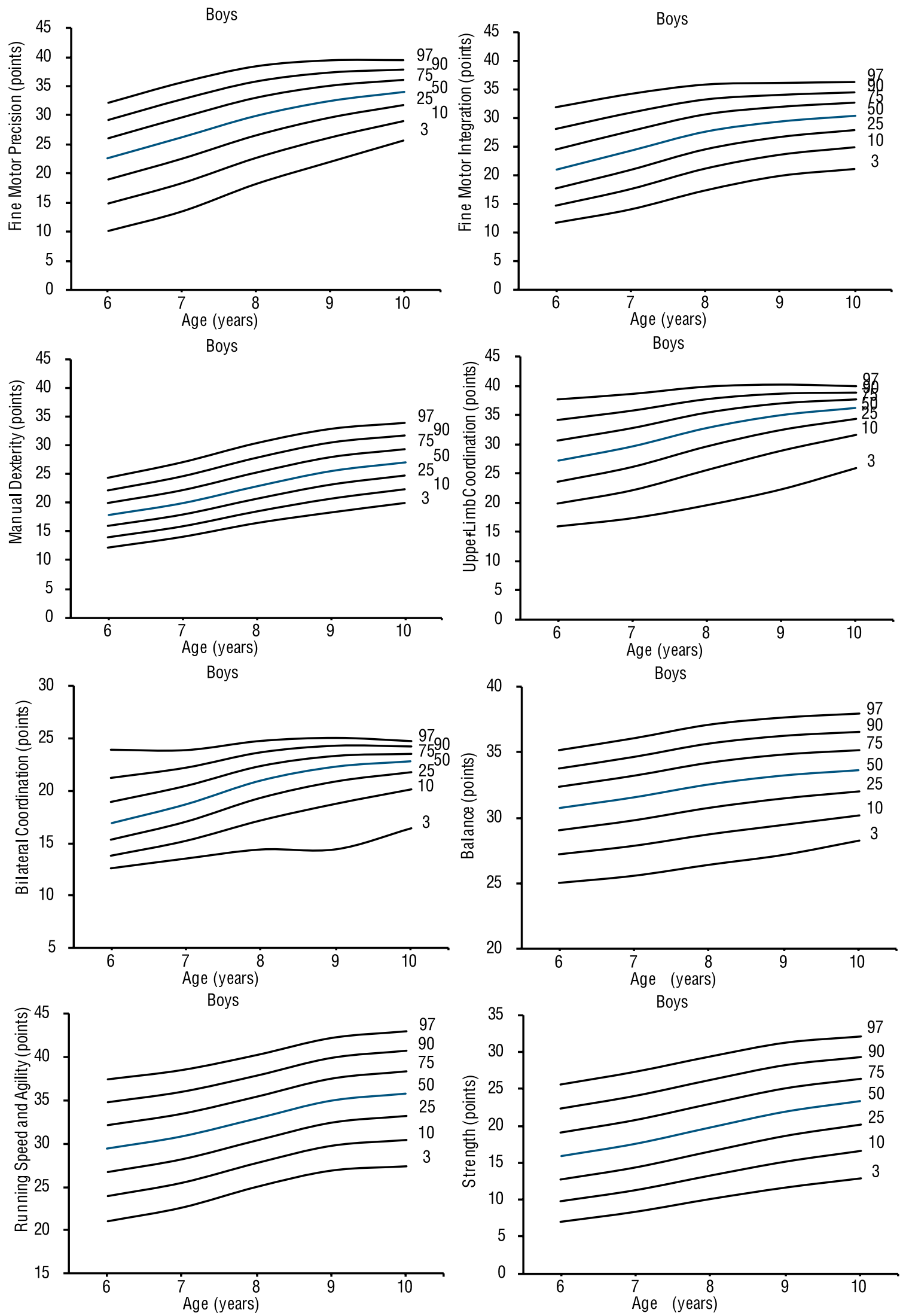

Figure 2. Percentage curves of the eight BOT-2 subtests for girls. 
American children showed higher performance on the subtests of fine motor precision, fine motor integration, manual dexterity, and muscular strength. However, when assessing manual dexterity, the curves superposed; the 8-yearold girls and the 6-9-year-old boys showed similar mean results. Brazilian children also showed better results in the subtests of bilateral coordination, balance, upper-limb coordination, and running speed and agility, with a difference range varying between 0.03 and 6.90 points. On the upper-limb coordination subtest, the curves showed similar mean values for both groups. The same happened for the balance subtest in 6-year-old girls, as seen in Figure 3.

It is estimated that values below the $10^{\text {th }}$ percentile correspond to low motor proficiency; and values between the $10^{\text {th }}$ and $90^{\text {th }}$ percentile are appropriate for every age and sex, which values above the $90^{\text {th }}$ percentile considered higher (Table 2).

\section{DISCUSSION}

The present study aimed at creating percentile curves for the eight BOT-2 subtests and comparing the motor proficiency of Brazilian children with the performance of North American children in the reference study ${ }^{6}$. Overall, the trajectory of the percentile curves suggests an increase in motor proficiency levels with age, in both sexes, corroborating with previous studies ${ }^{10,11}$. Logan et al. ${ }^{12}$ point out that motor skills performance tends to increase throughout life due to more effective participation of children in physical education programs.

It is worth emphasizing that in the present study the increase occurred between six and eight years of age; and after that, the curves showed either a constant increase in the subtest scores, or a plateau. Chaves et al. ${ }^{3}$, when analyzing the pseudo-speed curves for the four KTK battery tests, suggested that there might be a reduction in the annual gains for motor proficiency between 6 and 10 years of age, and these changes may be specific to each test and might be associated with gaps in motor learning opportunities. For example, the strong interindividual variability is expressed in values ranging between the $\mathrm{P} 3$ and the $\mathrm{P} 97$ in the different subtests. For example, in strength, the percentile curves at 6 years of age ranged from 6.95 points (P3) to 25.57 points (P97) for boys; and 6.33 points (P3) and 23.38 points (P97) for girls. This variation shows expressive differences in motor proficiency levels among children of the same age. These differences might occur due to individual biological characteristics ${ }^{13}$, the type of experience acquired that affect developmental changes during a specific period, as well influences of culture, family and social constraints ${ }^{14}$.

Regarding differences in the performance of BOT-2 subtests between sexes, girls showed better performance in fine motor precision, fine motor integration, manual dexterity and balance. The study ${ }^{15}$ with Brazilian children also demonstrated that girls showed higher values in balance, and there were similar results for Greek ${ }^{16}$ and Turkish ${ }^{17}$ girls, who demonstrated better performance in activities involving manual dexterity and balance. On 

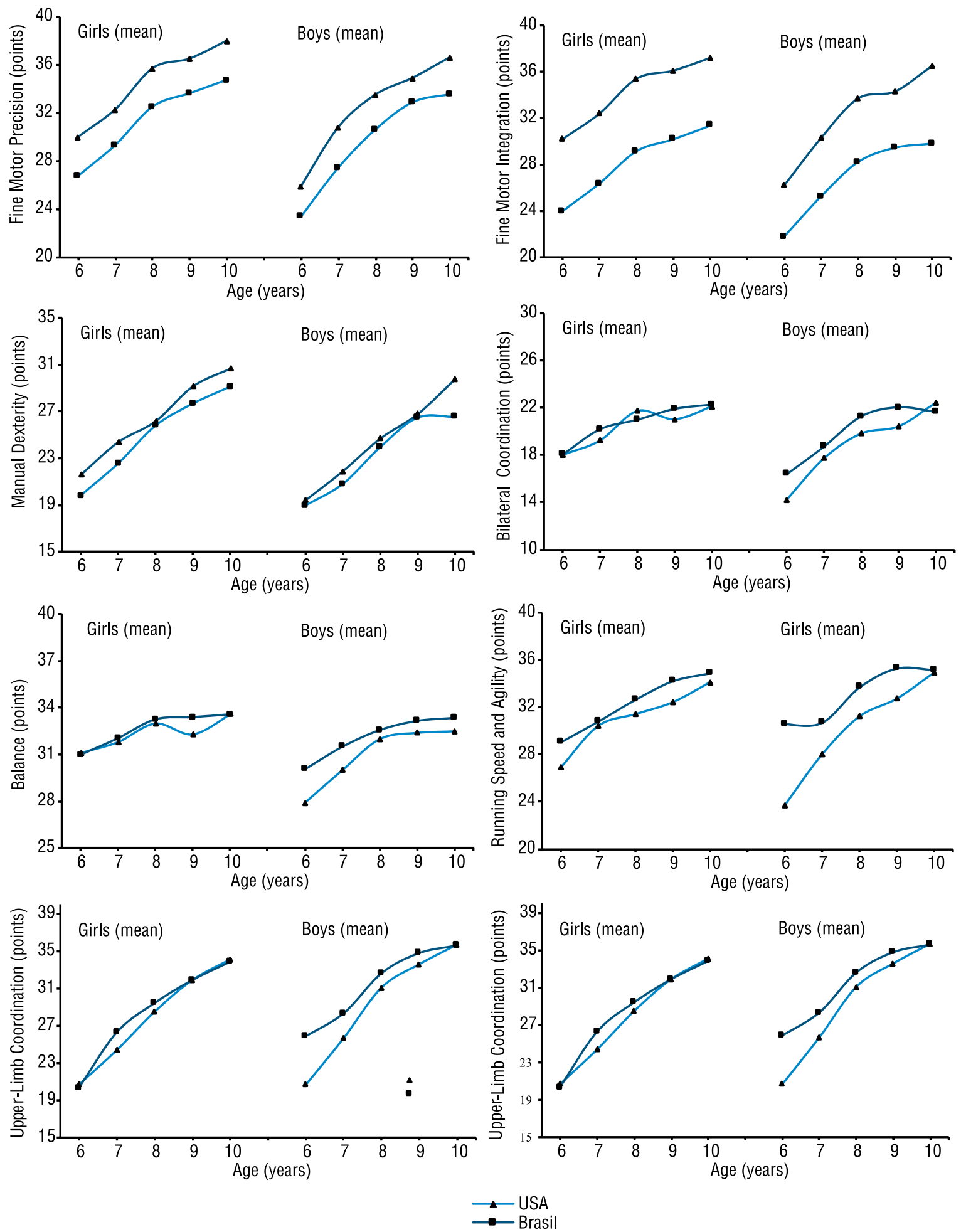

Figure 3. Comparison of the mean values of the eight subtests of the BOT-2 test with the values presented in the original test manual $(n=560)$.

the other hand, boys showed better performance in upper-limb coordination, running speed, and agility and strength. Similar results were reported with Brazilian ${ }^{15}$ and Greek boys ${ }^{17}$, respectively, who showed higher values for running speed and agility, and strength. The study ${ }^{18}$ found better values 
for upper-limb coordination of the boys from Hong Kong and the United States. Found better speed and agility performance for girls in England, but that was for younger children (6-to-7-year-old) ${ }^{19}$.

The differences can be justified by the different levels of physical activity reported by boys and girls ${ }^{20}$. Studies ${ }^{21,22}$ have reported that boys show significantly higher levels of physical activity and sport participation than girls. Culturally, boys are more encouraged to practice sports ${ }^{23}$, when compared to girls who are usually poorly encouraged ${ }^{4}$. Girls are typically oriented to practice manual activities, which include playing with dolls and educational toys ${ }^{24}$, in addition to a greater attribution of family and domestic chores ${ }^{4}$. Motivational aspects, especially concerning girls who tend to adopt less active behavior with increasing age, may have contributed to these results ${ }^{25}$.

When comparing the results of this study with the reference scores described in the BOT-2 manual, children from Brazil showed better performance in the four BOT-2 subtests: bilateral coordination, running speed and agility, balance and upper-limb coordination. These results can be explained due to sociocultural factors. Singer et al. ${ }^{26}$ pointed out that mothers of Brazilian children (69\%) are more concerned with their children's participation in outdoor activities than mothers of American children (12\%). American children, on the other hand, showed higher scores in tasks that require fine motor coordination (fine motor precision, fine motor integration, manual dexterity) and strength. The amplitude of these differences ranges between 3.21 points (6-year-old girls) and 3.25 points (10-year-old girls) in fine motor precision, for example. In a previous study by Valentini et al. ${ }^{27}$, American children had a higher level of total motor proficiency and better performance in the subtests of manual dexterity and ball skills, compared to Brazilian children (using the MABC assessment).

According to Singer et al. ${ }^{26}$, American children are more involved in small-screen activities, such as video and computer games, which might be helping their development of fine motor coordination. Plausible explanations for the differences in the present study may be related to restricted opportunities in Brazil for children to develop gross and fine motor skills ${ }^{20,27}$. In addition, according to Valentini, Clark and Whitall ${ }^{27}$, professional public services and opportunities to participate in early intervention programs are restricted in Brazil. In addition, it is not mandatory that physical education classes are taught by trained teachers ${ }^{20}$. However, other factors also interfere in motor proficiency performance, such as daily life routines, sociocultural factors of each population ${ }^{4}$ and the intrinsic motivation of each child ${ }^{28}$.

Several aspects of this study deserve consideration when assessing the practical implications of the results. It can be used as reference to describe children's motor proficiency, with specific normative values according to sex and age, and considering populations with characteristics similar to those of the sample in the present study. This might contribute to the adequacy of intervention programs and assessment of motor performance. In addition, the contribution in pedagogical and clinical terms is unquestionable, as it 
may assist Physical Education and movement professionals in general. It is worth mentioning that the sample size we used enabled accurate and robust percentile estimates in view of the estimation procedure implemented by Cole and Green's method ${ }^{29}$. Regarding the limitations, it is important to mention that this study did not account for all the contextual differences existing in a big and diverse country such as Brazil. However, we believe that the benefits might overcome the limitations, since this is the first study in Brazil that has established percentile curves for BOT-2 with school-aged children (6 to 10 years old).

\section{CONCLUSION}

In summary, the percentile curves obtained by the present study suggest the strong interindividual variability of motor proficiency in different BOT-2 subtests for the Brazilian population. The results were heterogeneous for boys and girls, as well as for Brazilian children in comparison to North American children. In general, the curves suggest the specificities for each subtest and sex, as well as the increase in scores for each test across ages. The use of the normative values shown in this study enables the interpretation of motor proficiency in 6-to-10-year-old children in Brazil, as well as the elaboration of more effective motor interventions. For a broad national characterization of motor proficiency, further studies are still necessary, especially those involving different regions with a stratified sample from all over the country.

\section{COMPLIANCE WITH ETHICAL STANDARDS}

\section{Funding}

Coordination for Improvement of Higher Education Personnel(CAPES) agency.

\section{Ethical approval}

Ethical approval was obtained from the local Human Research Ethics Committee -College Assis Gurgacz and the protocol (no. 1.207.141/2015) was written in accordance with the standards set by the Declaration of Helsinki.

\section{Conflict of interest statement}

The authors have no conflict of interests to declare.

\section{Author Contributions}

Conceived and designed the experiments: LF; RNC; JLLV. Performed the experiments: LF; JLLV; FC, FFR; PN. Analyzed the data: LF; RNC. Contributed reagents/materials/analysis tools: FC; FFR; PNS. Wrote the paper: LF; PC; RNC; JLLV.

\section{REFERENCES}

1. Gabbard C. Lifelong motor development. San Francisco: Pearson; 2008. 
2. Robinson LE, Stodden DF, Barnett LM, Lopes VP, Logan SW, Rodrigues LP, D'Hondt E. Motor competence and its effect on positive developmental trajectories of health. Sports Med 2015;45:1273-84.

3. Chaves RN, Tani G, Souza MC, Baxter-Jones A, Maia J. Desempenho coordenativo de crianças: construção de cartas percentílicas baseadas no método LMS de Cole e Green. Rev bras educ fís esporte 2013;27(1):1-17.

4. Valentini NC, Ramalho MH, Oliveira MA. Movement assessment battery for children-2: translation, reliability, and validity for Brazilian children. Res Dev Disabil 2014;35:733-40

5. Wuang Y, Lin Y, Su C. Rasch analysis of the Bruininks-Oseretsky test of motor proficiency-second edition in intellectual disabilities. Res Dev Disabil 2009;30(1):1132-44.

6. Bruininks R, Bruininks B. Bruininks-Oseretsky test of motor proficiency, second edition. Minneapolis: NCS Pearson; 2005.

7. Cools W, Martelaer K, Samaey C, Andries C. Movement skill assessment of typically developing preschool children: A review of seven movement skill assessment tools. J Sports Sci Med 2009; 8(1):154-68.

8. Pan H, Cole TJ. A comparison of goodness of fit tests for age-related reference ranges. Stat Med 2004;23(1):1749-65.

9. Buuren S, Fredriks M. Worm plot: a simple diagnostic device for modelling growth reference curves. Stat Med 2001;20(1):1259-77.

10. Vidal SM, Bustamante A, Lopes VP, Seabra A, Silva RG, Maia JA. Construção de cartas centílicas da coordenação motora de crianças dos 6 aos 11 anos da Região Autónoma dos Açores, Portugal. Rev port ciênc desporto 2008;9(1):24-35.

11. Valdívia AB, Lara R, Espinoza CB, Pomahuacre SQ Ramos GR, Seabra A. Prontitud coordinativa: Perfiles multivariados en función de la edad, sexo y estatus socio-económico. Rev port ciênc desporto 2008; 8(1):34-46.

12. Logan SW, Robinson LE, Wilson AE, Lucas WA. Getting the fundamentals of movement: A meta-analysis of the effectiveness of motor skill interventions in children. Child Care Health Dev 2011; 38(1):305-15.

13. Guedes DP. Crescimento e desenvolvimento aplicado à educação física e ao esporte. Rev bras educ fís esporte 2011;25(1):127-40.

14. Clark JE, Metcalfe J. The mountain of motor development: A metaphor. In: Clark JE, Humphrey J, organizers. Motor development: Research and reviews. Reston, VA: NASPE Publications; 2002. p. 163-190.

15. Miyabayashi LA, Pimentel GGA. Interações sociais e proficiência motora em escolares do ensino fundamental. Rev bras educ fís esporte 2011;25(1):649-62.

16. Venetsanou F, Kambas A. Motor proficiency in young children: A closer look at potential gender differences. Sage Open 2016; 6(1):1-10.

17. Mülazimoğlu-Balli Ö. Motor proficiency and body mass index of preschool children: In relation to socioeconomic status. Journal of Education and Training Studies 2016;4(1):237-43.

18. Chui MMY, Ng AMY, Fong AKH, Lin LSY, Ng MWF. Differences in the fine motor performance of children in Hong Kong and the United States on the Bruininks-Oseretsky Test of Motor Proficiency. Hong Kong J Occup Ther 2017;17(1):1-9.

19. Morley D, Till K, Ogilvie P, Turner G. Influences of gender and socioeconomic status on the motor proficiency of children in the UK. Hum Mov Sci 2015;44:150-56.

20. Valentini NC, Oliveira MA, Pangelinan MM, Whitall J, Clark JE. Can the MABC discriminate and predict motor impairment? A comparison of Brazilian and North American children. Int J Rehabil Res 2017;24(1):1-27.

21. Marques A, Ekelund U, Sardinha LB. Associations between organized sports participation and objectively measured physical activity, sedentary time and weight status in youth. J Sci Med Sport 2016;19(1):154-57.

22. Hebert JJ, Moller NC, Andersen LB, Wedderkopp N. Organized sport participation is associated with higher levels of overall health-related physical activity in children (CHAMPS Study-DK). PLoS One 2015;10(1):e0134621. 
23. Spessato BC, Gabbard C, Robinson L, Valentini NC. Body mass index, perceived and actual physical competence: the relationship among young children. Child Care Health Dev 2013;39(1):845-50.

24. Cherney ID, Lond K. Gender-linked differences in the toys, television shows, computer games, and outdoor activities of 5- to 13-year-old children. Sex Roles 2006;54(1):717-26.

25. Telama R, Yang X. Decline of physical activity from youth to young adulthood in Finland. Med Sci Sports Exerc 2000; 32(1):1617-22.

26. Singer DG, Singer JL, D'agostino H, Delong R. children's pastimes and play in sixteen nations is free-play declining? Am J Play 2009;1:283-312.

27. Valentini NC, Clark JE, Whitall J. Developmental co-ordination disorder in socially disadvantaged Brazilian children Child Care Health Dev 2014;41(1):970-79.

28. Bardid F, De Meester A, Tallir I, Cardon G, Lenoir M, Haerens L. Configurations of actual and perceived motor competence among children: Associations with motivation for sports and global self-worth. Hum Mov Sci 2016;50(1):1-9.

29. Cole TJ, Green PJ. Smoothing reference centile curves: the LMS method and penalized likelihood. Stat Med 1992;11(1):1305-19.

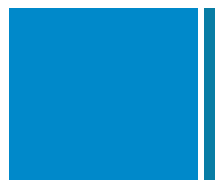

Corresponding author

Luciana Ferreira

Department Physical Education, State University of Parana

Gabriel Experidião avenue, Zip postal: 87.703-000, Paranavai - PR, Brazil.

E-mail: luferreira.ed@gmail.com 